\title{
MONITORING URBAN SPRAWL IN THE FEDERAL CAPITAL TERRITORY OF NIGERIA USING REMOTE SENSING AND GIS TECHNIQUES
}

*Ade, M. A. and Afolabi, Y. D.

http://dx.doi.org/10.4314/ejesm.v6i1.10

\begin{abstract}
Received 13th November 2012; accepted 11th January 2013

Urbanization in Abuja and its environs was largely due to the movement of the Federal Capital Territory to Abuja in 1991 causing the influx of internal/national and international migrants and natural increase of birth rate over mortality. This increase has not only put pressure on the city (Abuja) but the surrounding settlements by posing a threat to the limited resources thereby resulting to high cost of living. Abuja city was planned for limited people as opposed to what is obtained now. The research set out to measure the changes in landmass or landuse/landcover and population increase in the study area. Multi-date Satellite images of 1987, 1999 and 2007 (Landsat TM, Landsat ETM and Nigeriasat 1) were acquired from National Centre for Remote sensing Jos and used in analyzing the physical expansion of the city overtime. Using supervised classification algorithm, the images were classified into built up, rock-outcrop, vegetation and water bodies and used to carry out change detection or time series analysis. In addition, coordinates of locations in the area were obtained using a GPS while figures from National Population Commission were used. Change detection analysis was carried out on the imageries to obtain the physical expansion of the area. Using change detection method, it was found that the builtup area increased from $8 \%$ in 1987 to $22 \%$ in 2007 , rock-outcrop decreased from $74 \%$ to $37 \%$, vegetation decreased from $40 \%$ to $17 \%$, while the area occupied by water body has remained constant overtime. Also projection was done for population in the next nine years and 1,925,464.089 figures which are about $37 \%$ is expected. To support this increase in population and physical growth rate observed, constant monitoring of the urban growth is required to be sustained by anthropogenic activities.
\end{abstract}

Key words: Monitoring, Urban sprawl, Urbanization, Remote Sensing, Geographic Information System (GIS), change detection.

\section{Introduction}

Urbanization can be defined as changes in the general transformation of land-cover, and land-use categories (Kombe, 1998. Johnston et al 1981). There is an increasing interest in the use of Geographical Information System (GIS) and Remote sensing techniques to manage changes in an area i.e. territorial aspect of Urbanization. We can tackle these issues in a mega city, by capturing and analyzing land information trends. Such an effort will help manage cities expansion, as well as infrastructure development through the right choices, in planning and (spatial) designs using the latest tools in geospatial technologies of Geographic Information System (GIS) and Remote Sensing (Donny et al., 1999; Rao, 1995).

Natural increase in population (excess of birth over death) and migration to urban area are two factors said to influence rapid growth of urban area; Migration is defined as the long-term relocation of an individual household or group to a new location outside his community of origin. Both internal and international migrations contribute to urbanization. Migration is often explained in terms of either "push factor" conditions in the place of origin or "pull factor" better opportunities. Push factors which are perceived by migrants as detrimental and pull factors as opportunities in new places that attract individuals to move there. Examples of pull factors include job opportunities or moving to a better climates. Example push factors include high unemployment and political persecution (Hardoy and Satterthwaite, 1995; Akrofi, 2006, Agboola, 2009).

The urban sector of any country is never static. It changes per time. In fact, as days and years go by the urban landscape is altered. Development as well as growth in infrastructural amenities affects the land use/land cover. Urban Abuja is not an exception since it was created in 1976 (Ago, 
2001).Though there was nothing to be called "Abuja city" and almost everywhere was covered with rocks, vegetation, bare land and little water bodies; it could be scarcely be referred to as an urban area. However, as development (growth) began to take place such as movement of the Federal Capital Territory from Lagos to Abuja, it gave the city a new look with a promise performance and prospect (Mabogunje, 2001 Olujimi, 2009). The urbanization of Abuja also affects the surrounding towns and settlements by posing a threat to the limited available resources there by resulting to high cost of living (Ekoh et al., 2006). It is in a bid of addressing this increase that the research wants to ascertain how much growth has occurred within Abuja city between 1987 and 2007(period of 20 years), know the trend of Abuja city growth,rate of growth,the anticipated projected growth, and seek ways of how it can be handled.

Observing the growth of Abuja as an urban centre is not as easy task (Shuaib, 2000 Rasaki, 1988), various methods can be used in arriving at the growth rate of the city and its environs. Geographically, the rate of urbanization change of Abuja and its environs has been on the increase. These changes have affected land use/ land cover of the city (Cleveland, 2008). Statistical data could be employed in monitoring these changes, however for easy and straight forward approach, Remote Sensing and GIS techniques are preferable (Oluseyi, 2006; Hai, and Yamaguchi, 2004).

It is on this basis that the study employed the preferable approach to monitor the rate of urbanization change in Abuja and its environs in order to solve this problem. Remote Sensing and Geographical Information System (GIS) techniques were used to assess the rate of change that has occurred in Abuja city and some of its environs within the last 20 years and to also note if the rate of urbanization is a problem to the city and how could it be solved. The objectives set to achieve the aim were:

1. Analyze urbanization change between 1987, 1999 and 2007,
2. To assess the trends in the physical expansion of the city,

3. To forecast the future population in the area,

4. To find out the rate at which the Abuja city is developing in relationship with the factors behind urbanization in the study,

5. To compare the rate of growth of the city to the available resources and check the balance between the two and to provide suggestion that can enable planners contribute to the improved land use administration (Debliy, 1996).

\section{Study Area}

A new Federal Capital Territory was created in Abuja on $3^{\text {rd }}$ Feb. 1976 through the promulgated Federal Capital Territory decree no. 6, 1976 mainly due to the growing unsuitability of Lagos as Nigeria's Federal Capital City as result of the problem of peripheral location. Also the issue of dual and conflicting role as both federal and state capital, acute shortage of land space for expansion, and inadequacies for infrastructural development among other reasons since the late 1960's. Abuja is Nigeria's Federal Capital Territory (FCT) and city. It is located in the middle of the country and has a land area of about $8,000 \mathrm{~km}^{2}$ of which the actual city (i.e. Federal Capital City) occupies $250 \mathrm{sq} \mathrm{km}$ and bounded on the north by Kaduna state, on the west by Niger state on the east and south-east by plateau state, and on the south-west by Kogi state. It lies within latitude $9^{0} 25^{\prime} \mathrm{N}$ and $9^{0} 20^{\prime} \mathrm{N}$ of the equator and longitude $5^{0} 45^{\prime} \mathrm{E}$ and $7^{0} 39^{\prime} \mathrm{E}$ also the entire image falls within latitude $9^{0} 15^{\prime} \mathrm{N}$ and $8^{0} 56^{\prime} \mathrm{N}$ of the equator and longitude $7^{0} 09^{\prime} \mathrm{E}$ and $7^{0} 34^{\prime} \mathrm{E}$ (Figures 1 and 2). It is situated within the Guinea Savannah vegetation zone of the West African sub-region with moderate climatic conditions. Patches of rain forest however, occur in the Gwagwa plains especially in the gullied train to the south and the rugged south eastern parts of the territory. 


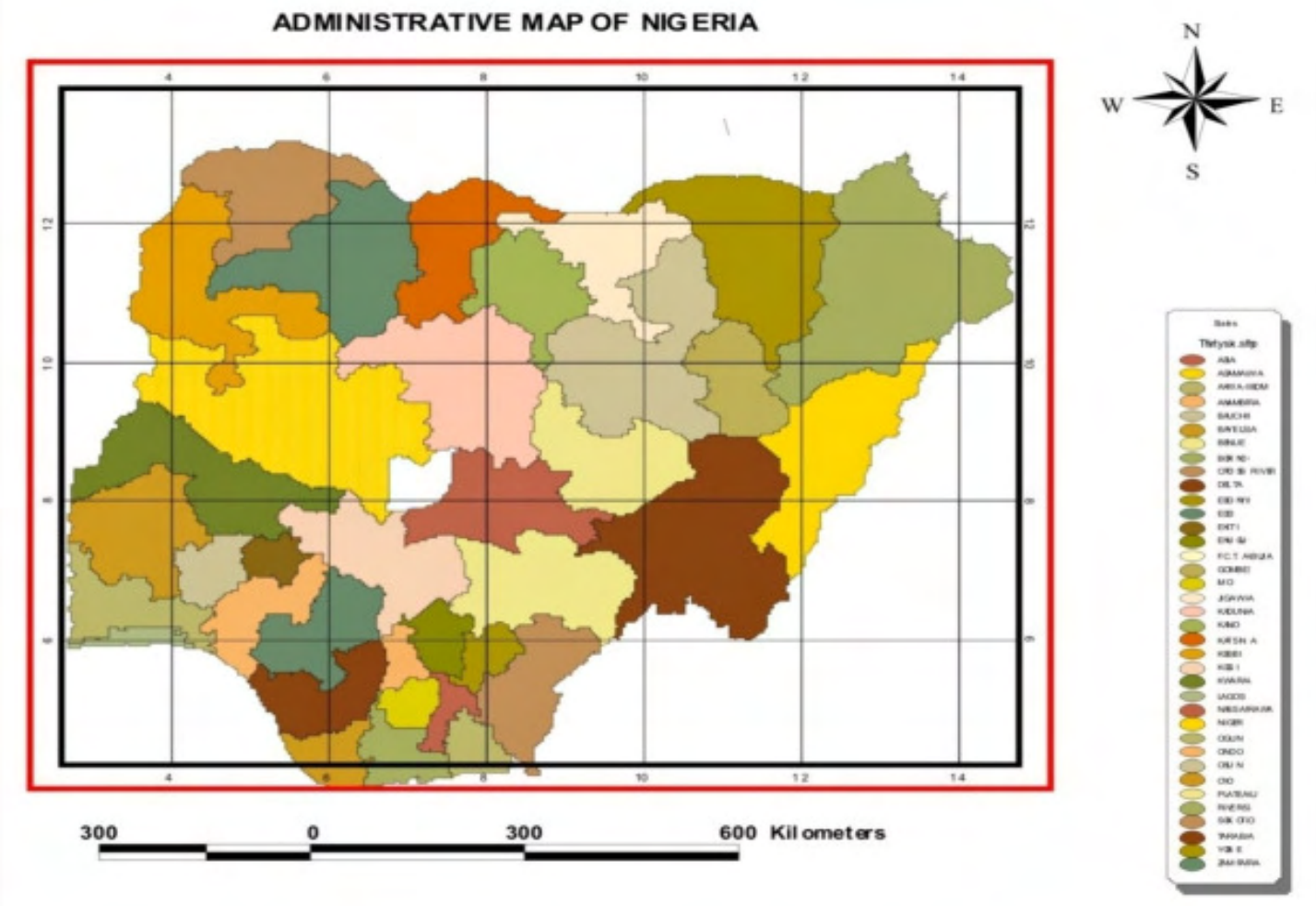

Figure 1 Map of Nigeria

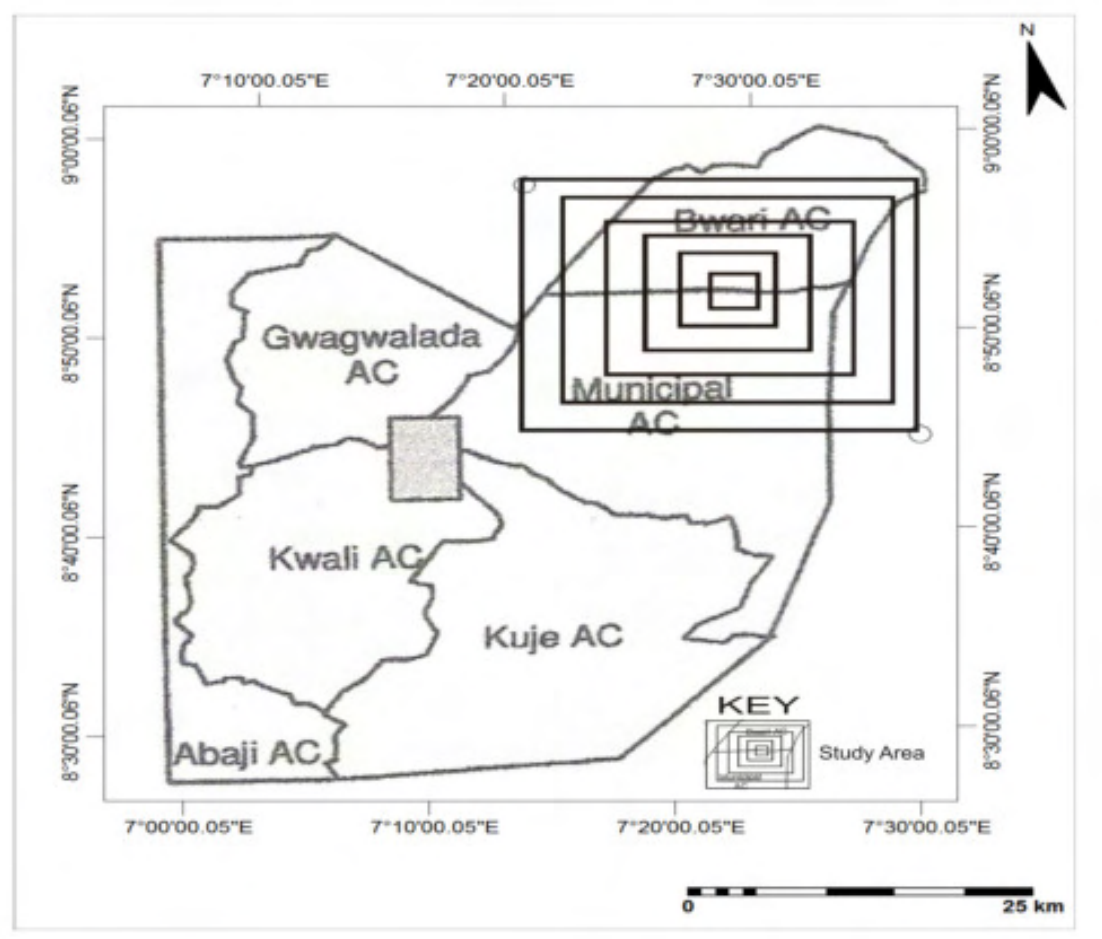

Figure 2 Study Area 


\section{Methodology \\ Sources of Data}

Three types of data set were used in the course of this study; these are satellite images, Landsat TM, Landsat ETM image for the years 1987, and 1999. Nigeriasat-1 image was used for the year 2007. Geographic Position System (GPS) was used to get the coordinates of some locations in the study area. National Population Commission (NPC) figures were used to get the population statistics of the study areas for some years. Internet Google earth was used to get the plates used.

The satellite images were geo-referenced using the ILWIS software (Integrated Land and Water Information System) and projected to the universal Transverse Mercator (UTM) coordinates zone 32, WGS 1984. The standard image processing techniques of image extraction, extraction, rectification, restoration and classification were carried out. Since the images were in bands, rearrangement of the bands to get the right band combinations that will show reflections of different features under investigation correctly a true colour composite was generated. The images were sub mapped to $18613.32467 \mathrm{~km}^{2}$ on map and $18613.31376 \mathrm{~km}^{2}$ ellipsoidal distances to cover Abuja city and its environs. ILWIS 3.0 was used for image re-sampling, image sub map, segment map, sample set and ILWIS 3.6 Academic for classification and to check for error and accuracy after polygonizing. It is the submapped area that was analyesd. The imageries were categorized using a module Maximum Likelihood Classification (MLC) technique.

The classification of land use of different categories was aggregated to built-up area (residential and commercial), vegetation/green area, and rock outcrop and water bodies. Coordinates of locations in sample area representing the DNS (reflections) of the different categories were gotten with the use of the GPS as identified on imageries. The patches were digitized, vectorized and calculated. After classification, the attributes of the classified images was used to generate the change to determine how much change has occurred, its trend, nature and rate.

\section{Development of Classification Scheme}

Based on the prior knowledge of the study area, a classification scheme was developed after
Anderson et al (1962). Modification of Andersons' (1976) land use/ land cover classification scheme is adapted. The value or code given to Built-up area is 1, Vegetation 2 Rock out crop 3 and Water bodies 4 .

\section{Data Analysis}

The methods of Data Analysis included Calculation of the area in hectare of the resulting land use land cover types for each study year to see the rate of change and subsequently comparing the results, The Markov Chain and Cellular Automata Analysis for predicting change, Overlay operations, Maximum likelihood classification and Land consumption rate and absorption coefficient were utilized.

The first three methods above were used for identifying change in the land use types. The comparison of the land use/ land cover statistics assisted in identifying the percentage change, trend and rate of change between 1987 and 1999, and 2007 and 1987 and 2007.

Trend Percentage Change $=($ Observed Change $/$ Sum of Change) x 100.

The second method (Markov Chain Analysis and Cellular Automata Analysis), Identifies the actual location and magnitude of change although this was limited to the built-up land, the Land Consumption Rate (LCR) and Land Absorption Coefficient (LAC) formula.

The 2016 population figure was estimated through the use of the National Population Commission (NPC) censuses and estimates, 2008 figures. A growth rate of $3.2 \%$ pa was obtained from the 2006 census.

\section{Accuracy Assessment}

Pixels were chosen throughout the study area (image) after which ground truth was done and compared with the classified map, which matched. Enough random pixels were checked and the percentage of accurate pixel gave a fairly good estimate of accuracy of whole map.

\section{Result and Discussion}

The growth dynamics of Abuja city from 1987 to 2007 was digitized from the classified images and polygonized. A GIS overlay operation which shows the growth extent of Abuja between 1987, 1999 and 2007 as well as the changing pattern of land use between 1987, 1999 and 2007 are shown in Figures 3, 4 and 5 and summarized in Tables 1, 2 and 3. 


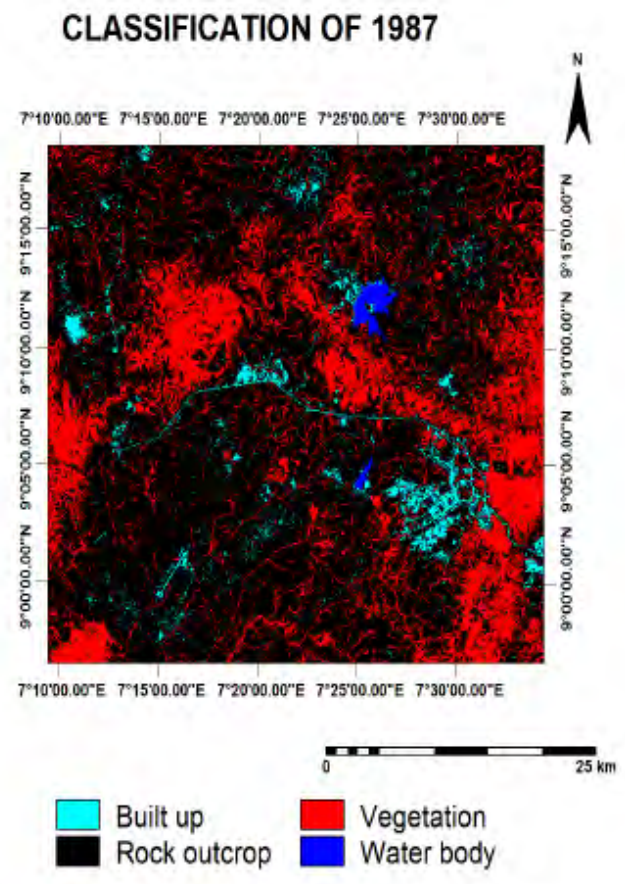

Figure 3 Classified Map of study Area 1987

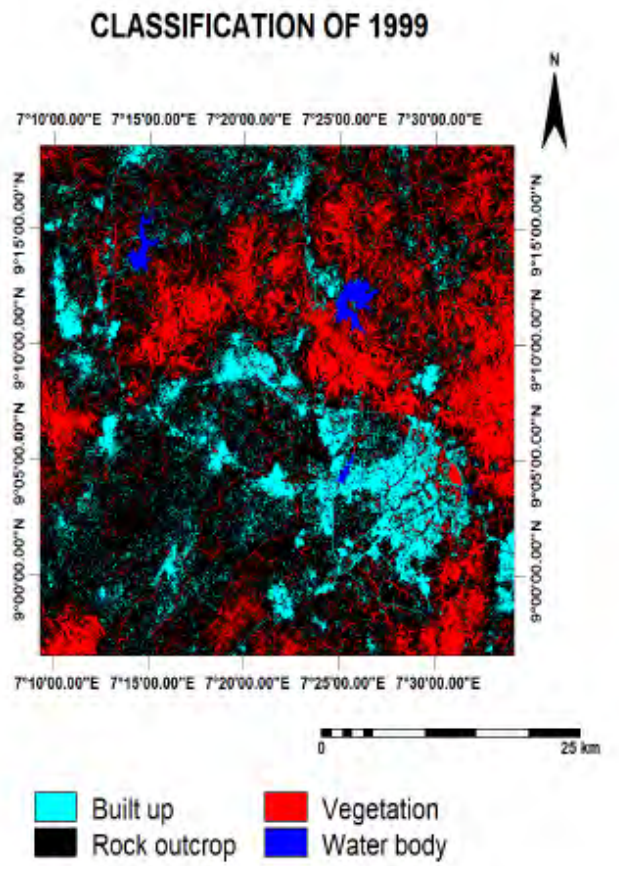

Figure 4 Classified Map of Study Area 1999

\section{CLASSIFICATION OF 2007}

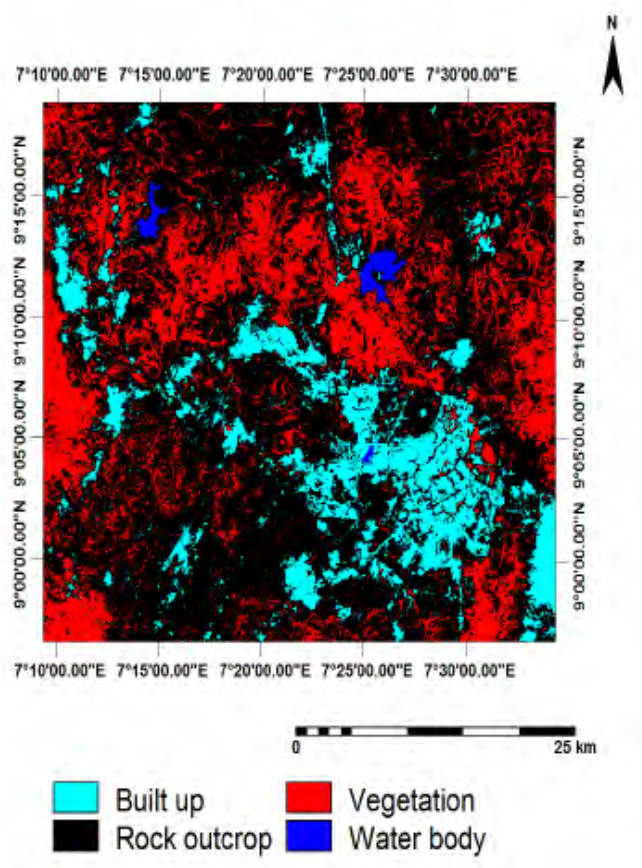

Figure 5 Classified Map of Study Area 2007

Source: National Center for Remote Sensing, Jos 
Table 1 Urban Change Trend

\begin{tabular}{|l|l|l|l|l|l|l|}
\hline Year of Study Area & $\begin{array}{l}1987(\text { area in } \\
\left.\mathrm{km}^{2}\right)\end{array}$ & $\%$ & $\begin{array}{l}1999(\operatorname{area} \text { in } \\
\left.\mathrm{km}^{2}\right)\end{array}$ & $\%$ & $\begin{array}{l}2007(\text { area in } \\
\left.\mathrm{km}^{2}\right)\end{array}$ & $\%$ \\
\hline Built-up & 78.75 & $4 \%$ & 147.22 & $8 \%$ & 416.22 & $22 \%$ \\
\hline Rock Outcrop & 1445.31 & $77 \%$ & 1383.63 & $74 \%$ & 696.86 & $37 \%$ \\
\hline Vegetation & 738.54 & $40 \%$ & 329.09 & $18 \%$ & 319.09 & $17 \%$ \\
\hline Water Body & 15.04 & $1 \%$ & 14.41 & $1 \%$ & 12.93 & $1 \%$ \\
\hline Total Area & 1864.35 & & 1864.35 & & 1864.35 & \\
\hline
\end{tabular}

Table 2 Rate and Magnitude of Change

\begin{tabular}{|l|l|l|l|}
\hline Year of study area & $\begin{array}{l}\text { Change between } 1987 \\
\& 1999\end{array}$ & $\begin{array}{l}\text { Change between 1999 \& } \\
2007\end{array}$ & $\begin{array}{l}\text { Change between } 1987 \text { \& } \\
2007\end{array}$ \\
\hline Built-up & 68.47 & 269 & 337.47 \\
\hline Rock Outcrop & -61.68 & -686.77 & -748.45 \\
\hline Vegetation & -5.81 & 419.45 & 413.64 \\
\hline Water Body & -0.99 & -148 & -2.47 \\
\hline
\end{tabular}

Table 3 Trend Percentage Change

\begin{tabular}{|l|l|}
\hline Year of Study Area & Built Up \\
\hline Change between $1987 \& 1999$ & 68.5 \\
\hline Observed change/ Sum of change $\times 100$ & $68.47 / 674.94 \times 100=10 \%$ \\
\hline Change between $1999 \& 2007$ & 269 \\
\hline Observed change/ Sum of change $\times 100$ & $269 / 674.94 \times 100=40 \%$ \\
\hline Change between $1987 \& 2007$ & 337 \\
\hline Observed change/ Sum of change $\times 100$ & $337.47 / 674.94 \times 100=50 \%$ \\
\hline
\end{tabular}

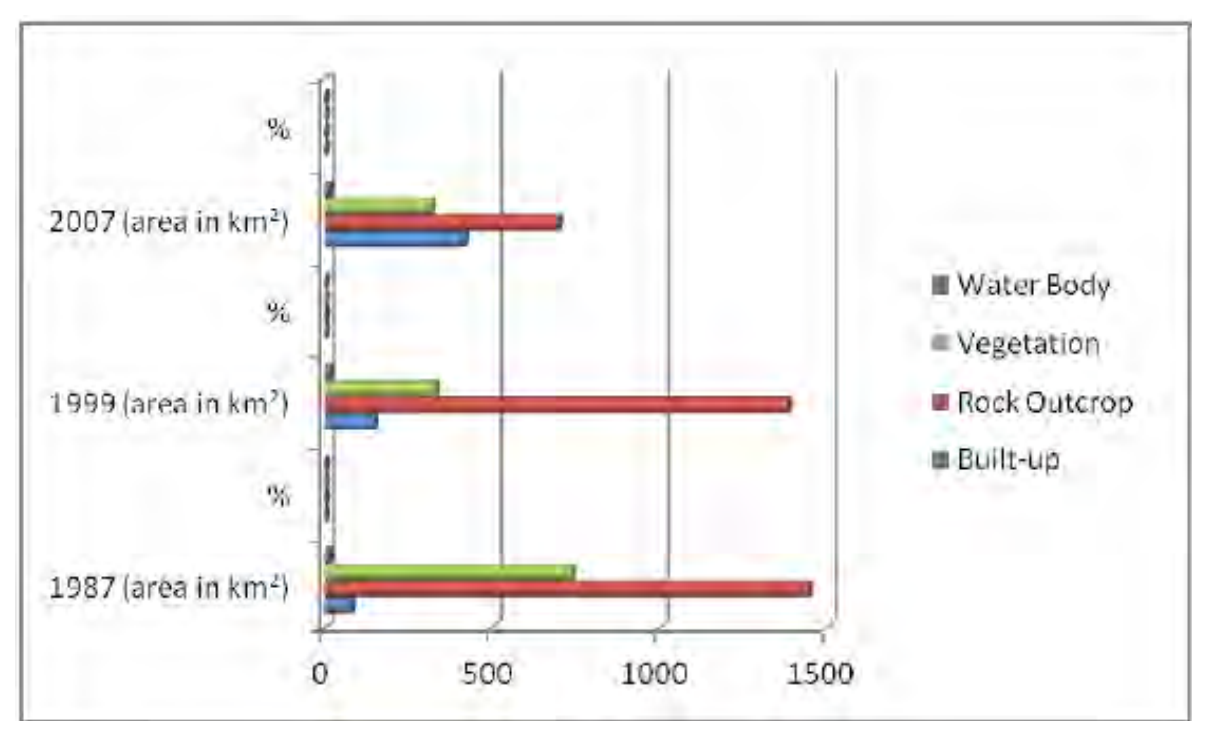

Figure 7 Chart Area Covered by each Landuse/landcover 


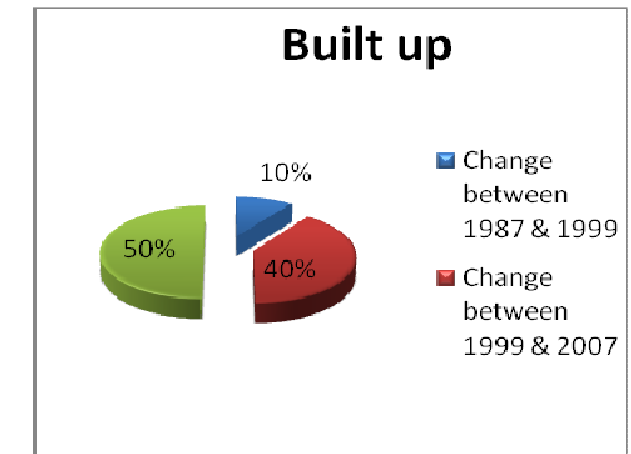

Figure 8 Pie Chat of Trend Percentage Change

\section{9 (area in $\mathrm{km}^{2}$ )}

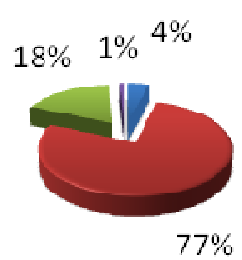

จ Built up

ㅁock

outcrop

$\square$ Vegetation

Water body

Figure 10 Pie chart showing areas in year 1999 and its Percentage Rates

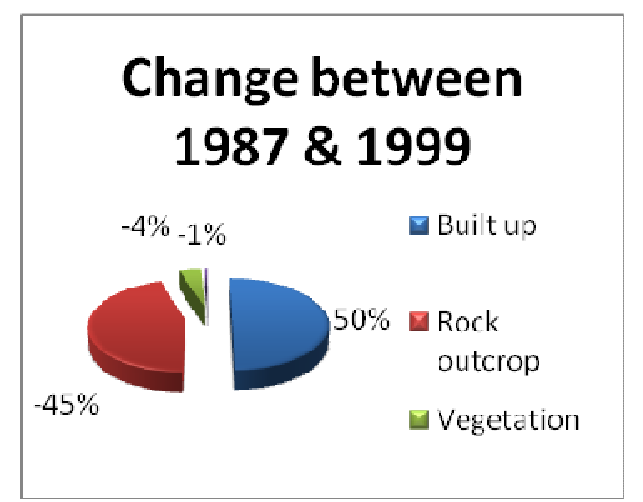

Figure 12 Pie chart showing areas changes occurred in both years

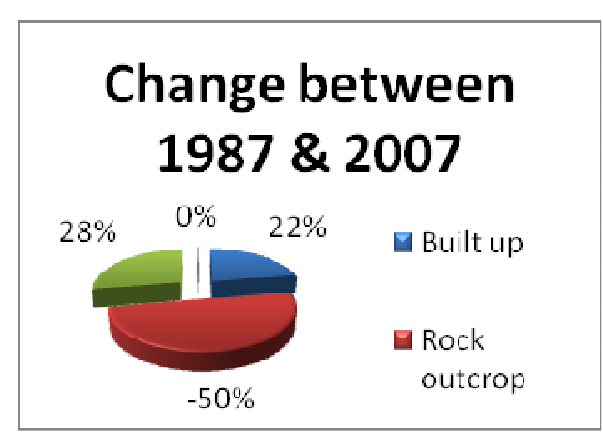

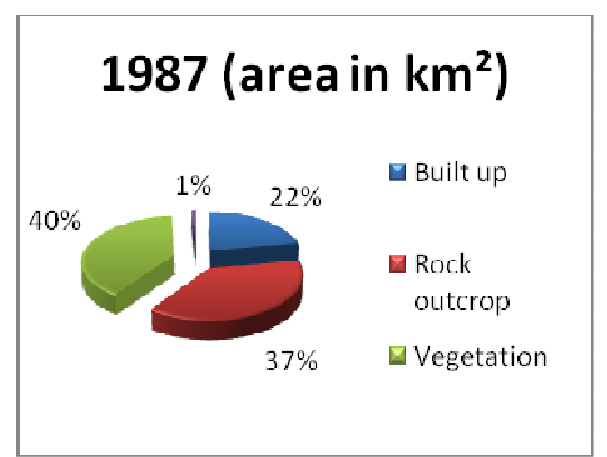

Figure 9 Pie Chart Showing Areas in Year 1987 and its Percentage Rate

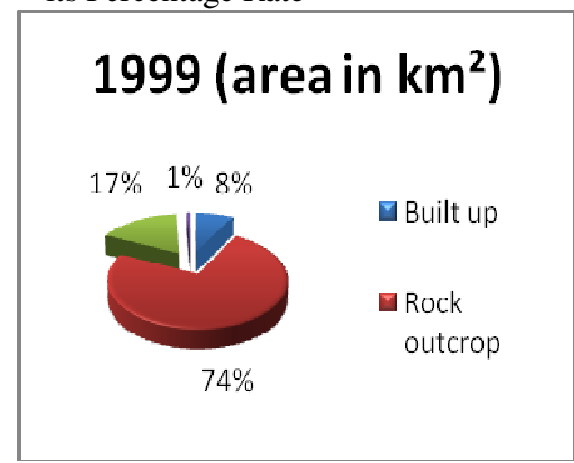

Figure 11 Pie Chart Showing Area in Year 2007 and its percentage rates

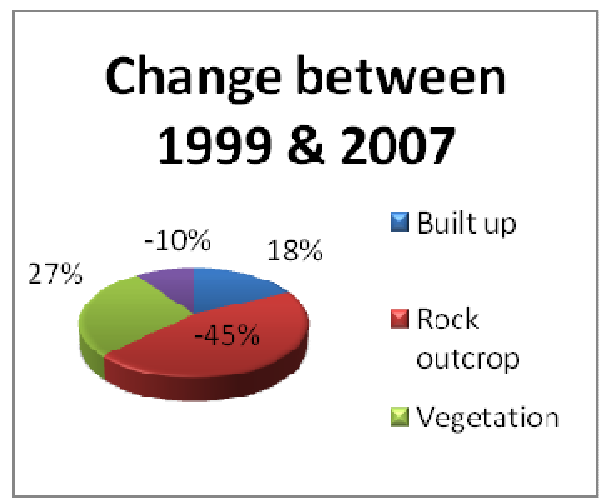

Figure 13 Pie chart showing areas changes occurred in both years

Figure 14 Pie Chart Showing Areas Change Occurred in 1987 and 2007 
From Table 1 it is clearly indicated that built-up area increased from $78.75 \mathrm{~km}^{2}$ in 1987 to 147.22 $\mathrm{km}^{2}$ in 1999 and then to $416.22 \mathrm{~km}^{2}$ in 2007 and an increase from $4 \%, 8 \%$ and $22 \%$ respectively. This is due to the urbanization of city (people are attracted to come and earn a living). From figure 8 to 14 we could see change in all the different classes between the different years as presented in table 2, while figure 7 , and table 3 shows the builtup trend which was $10 \%$ from 1987 to 1999 and 40\% from 1999 to 2007 then causing a large change of $50 \%$ from 1987 to 2007 (20 years).

It is worthy of note from the above that the urban sector of any country is never static, it changes per time in fact as days and years go by they affect the structural topography of the urban areas. Also development as well as growth in infrastructural amenities affects the landuse / landcover

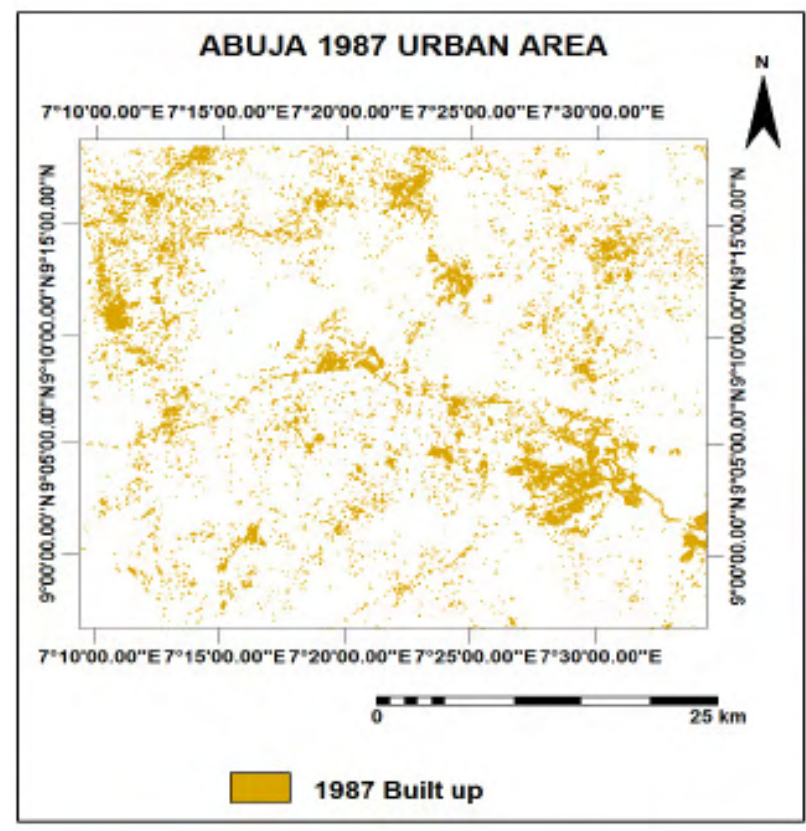

Figure.15 Map Showing Abuja Urbanization Extent in 1987

\section{Growth Dynamics of Abuja city}

Having classified all imageries of 1987, 1999 and 2007 built-up area of the city as digitized and polygonized, the three thematic layers were then overlaid on each other. The polygonized maps are presented in the figures $15,16,17,18,19,20$ and 21 . Figure 15 shows the extent of urbanization in 1987 thereby presenting $0 \%$ of the growth due to the fact that it's our base year for this work. Figure 16 shows the extent of urbanization in 1999 with $44 \%$ of the growth rate, while Figure 17 shows the extent of urbanization in 2007 with $56 \%$ of the growth rate. From 1987 - 2007 which is seen in figure $18,19,20$ and 21 as the overlay of all the three thematic layers shows how this growth extends.

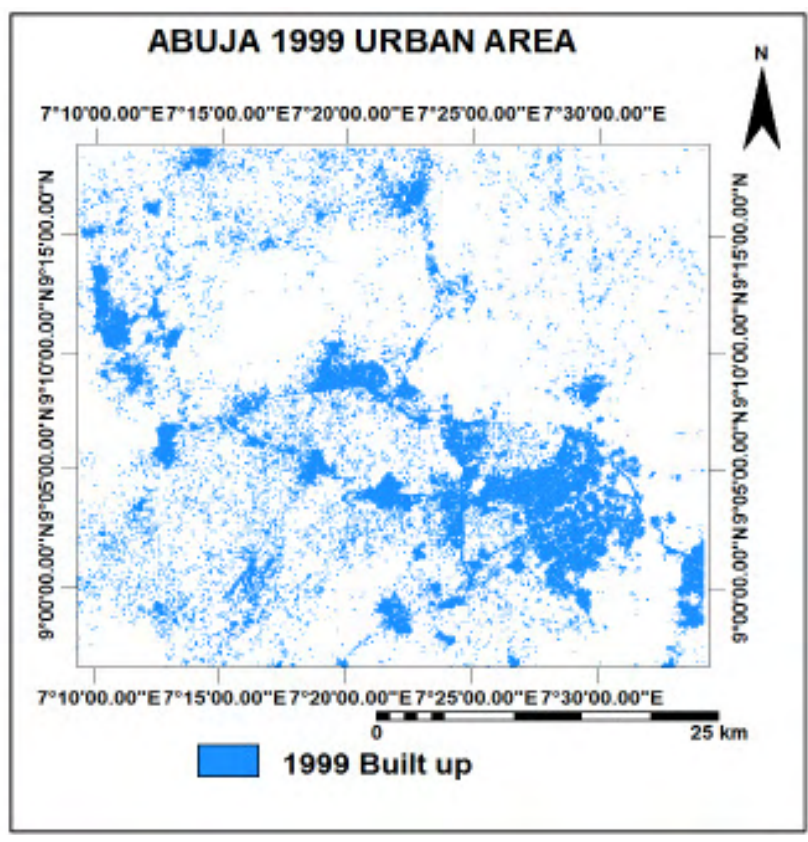

Figure 16 Map Showing Abuja Urbanization Extent in 1999 


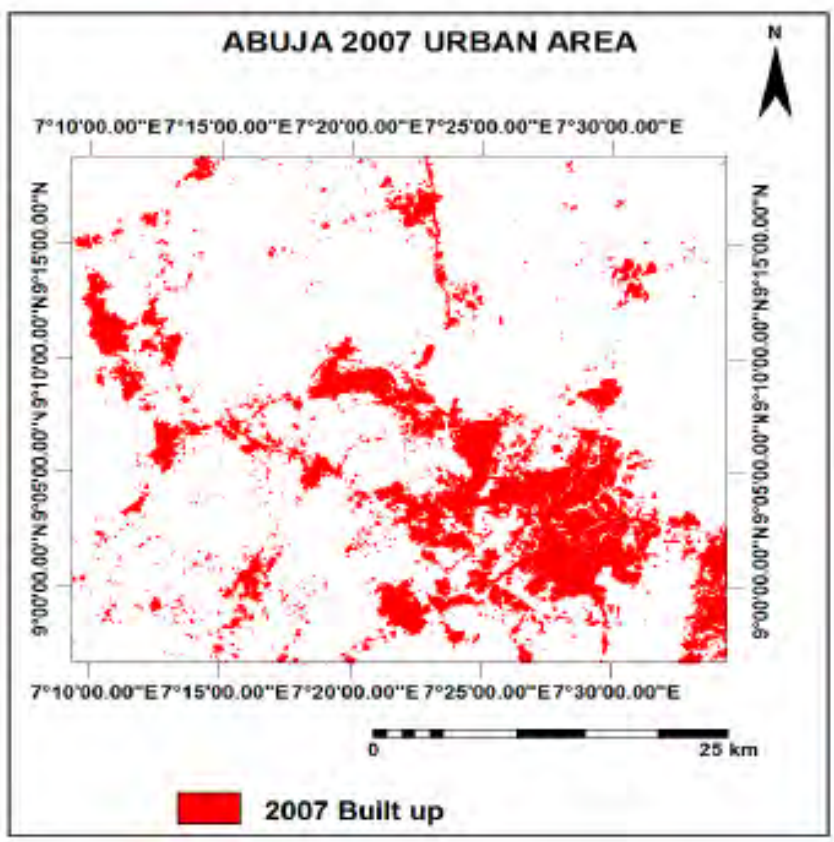

Figure 17 MapShowing Abuja Urbanization Extent in 2007

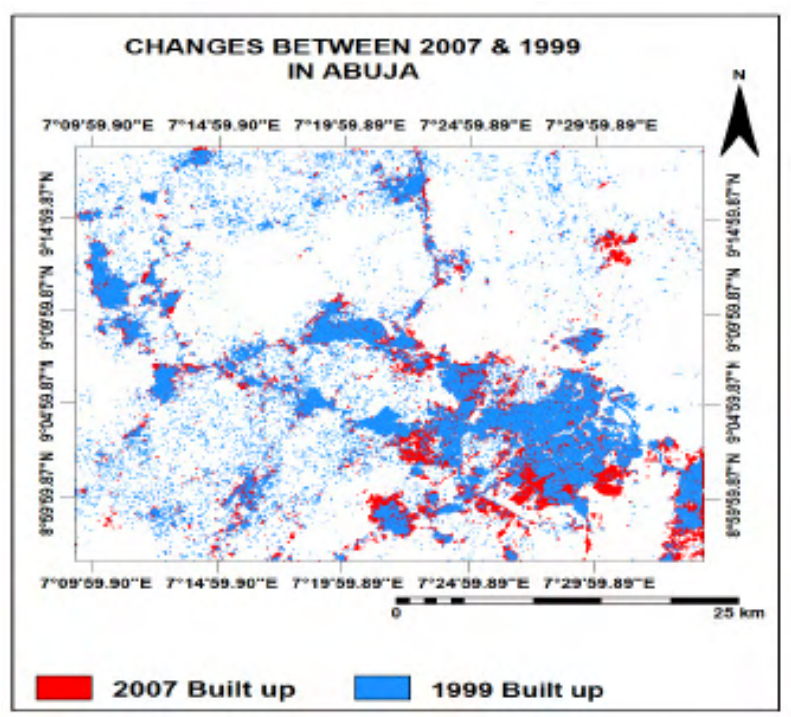

Figure 19 Map Showing Overlay of 1999 and 2007 Urbanization Extents

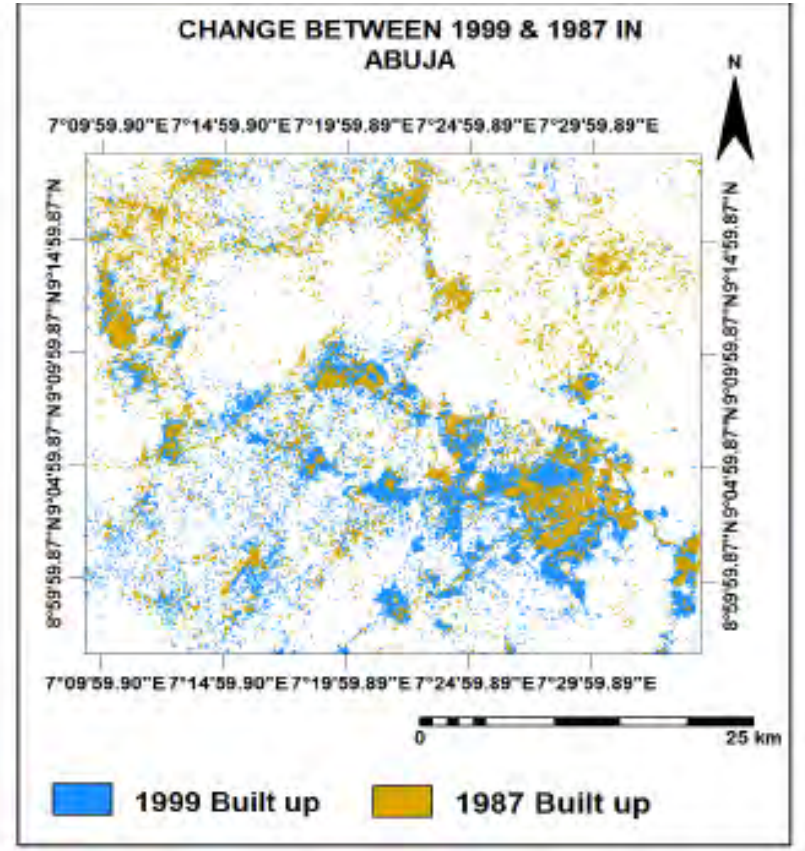

Figure 18 Map Showing Overlay of 1987 and 1999

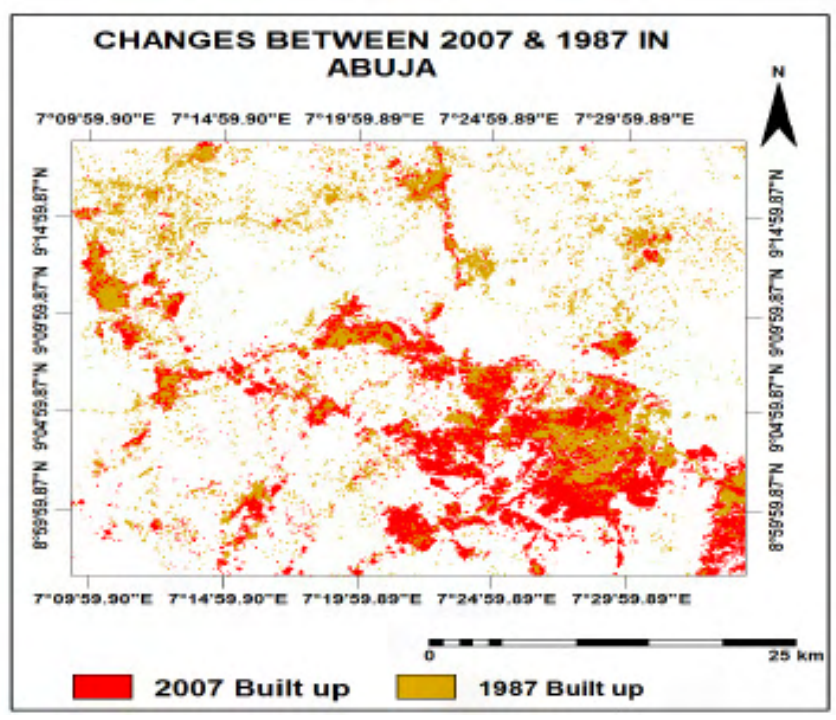

Figure 20 Map Showing Overlay of 1987 and 2007 Urbanization Extents 


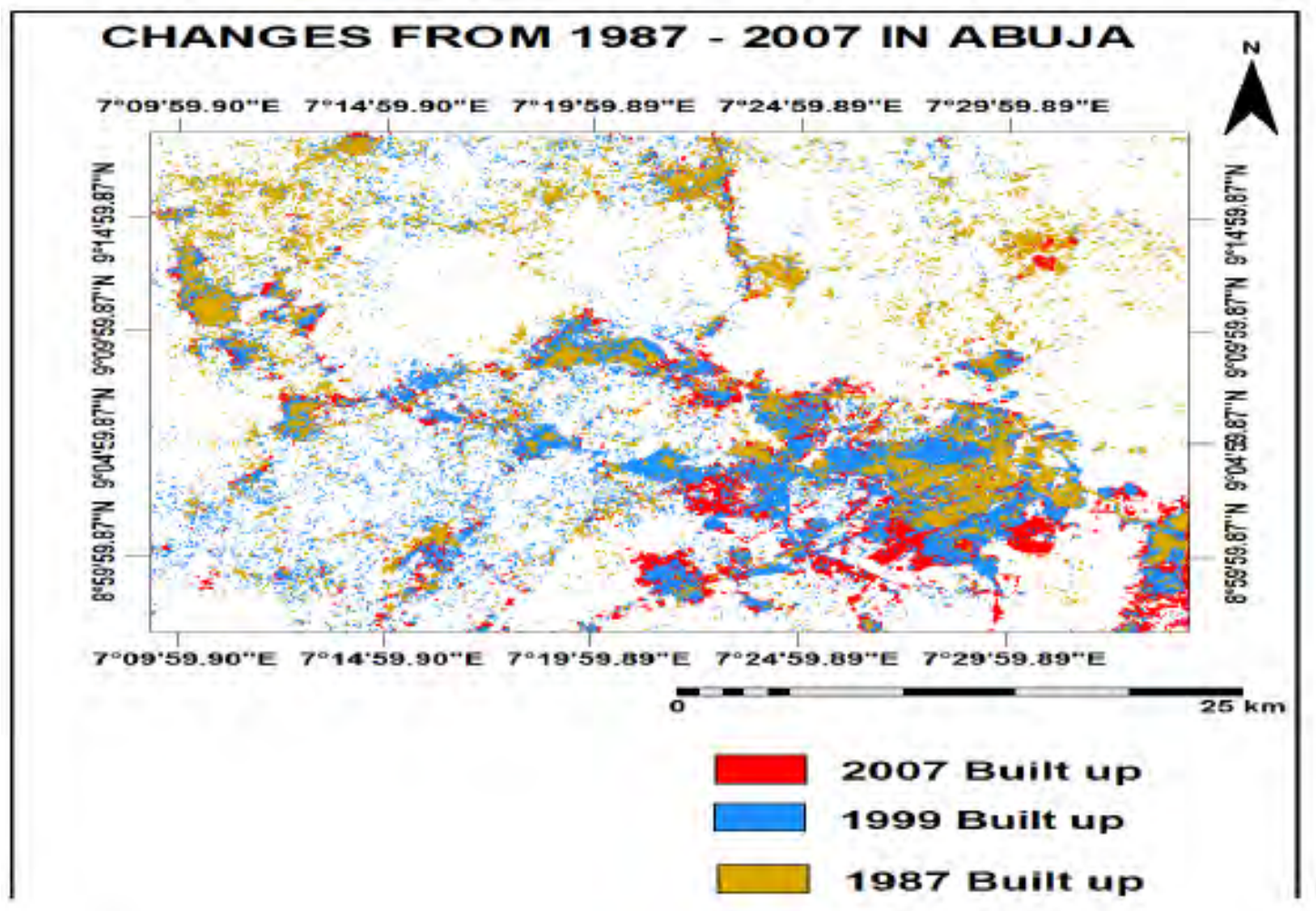

Figure 21 Map Showing Overlay of 1987 - 2007 Urbanization Extents

From figures 15, 16 and 17 the extent of land area covered by the town keeps increasing as reflected in figure $18,19 \& 20$. The extent in 1987 was $49.97 \mathrm{~km}^{2}$ which then increased to $93.77 \mathrm{~km}^{2}$ in 1999 and further increased to $179.48 \mathrm{Km}^{2}$ in 2007. Figure 18 shows the growth rate between 1987 and 1999. This growth is shown in figure 21 which is the overlay of all the years. The effects of this growth to the satellite towns adjoining the main city is Sprawl resulting in an outward spread of built up areas caused by their expansion. This has brought about haphazard housing development in the urban suburbs without planning permit in uncoordinated layout Olujimi (2009). These areas lacks essential social and welfare infrastructure like water, electricity etc and Often times, these structures are products of squatters that choose to settle at the suburbs as a result of their inability to afford residential accommodation in the city. The improper coordination of the physical development promotes high level of inaccessibility within the area and causes serious traffic along routes connecting these areas and the city particularly early mornings and closings hours of the working class.

From the analysis there is a significant threat of urban growth in many ways than one to the city and environs such as clearing of natural vegetation and its replacement with other activity. There has been a marked decrease in vegetation and outcrop which as observed in due to urban growth. Vegetation clearing is the major threat to bio-diversity and many cause species extinctions by reducing and fragmenting available habitat. Some reasons backing the urbanization increment of Abuja have been discussed earlier. This discussion can further be supported by the population study below about Abuja.

Population dynamics is an important component for national and urban sustainable development. An increase in total population citeris paribus leads to an increase in the demand for goods and services and in turn puts pressure on environmental resources. As earlier stated, population dynamics are the underlying drivers of development and environment changes in Abuja. The population of Abuja like that of other urban centers in the country has been increasing. This has 
mainly been due to high birth rate increase, decline in mortality, Internal and international migrations. Abuja has continued to be a primate city and a hub of economic, social, commercial, industrial and political activities that attract both internal and external migrants. Migrants are both temporary and permanent explaining why Abuja resident population is always increasing. The trend and projections estimate was derived. The population increase naturally creates adjustment and readjustment of human and land use activities in space within urban systems thus causing lateral and structural changes. Lateral changes occur when the city expands in geographic boundaries leading to sprawl and peripheral developments while structural growth relates to increase in land use density within urban centre Oluseyi (2006). The low-density areas gradually become subjected to intensive use and thus become high density or medium density use.

Many writers confirmed that Nigerian urban centre's are faced with rapid growth and development which of course collaborates the researchers findings. Oluseyi (2006) observed that the relationships between population increase, economic developments and land use change have generated research interest over two decades and half. The pattern and direction of sprawl developments in many cities in Nigeria are limited by physical barrier such as lagoon, Rocky Mountains and other natural features, the influx of people into the cities complicated the urban condition through structural growth (Oluseyi 2006).

Olijimi (2009) observed that one significant feature of the urbanization process in Nigeria and most of the developing countries is that, unlike America and Europe, much of the growth is taking place in the absence of significant industrial expansion. In Nigeria, all cities apart from Abuja are organic in their origin and developed over a long period of time as build- on for existing precolonial urban centers.

According to Agoola (2009) urbanization is a product of some factors which includes natural increase in population (National growth rate) or ratio of birth to death rate, Rural -Urban migration and City annexation into the surrounding rural areas (a real expansion) Shuiab (2000), further argued that urbanization is characterized by exploding urban centre's with steadily growing economies. Other features include being centers of production, employment, innovation and characterized by negative tendencies such as disproportionalities, urban sprawl, social services and infrastructure deficiencies.

Olarewanju 2008 observed that anthropogenic drivers such as urbanization and economic dependence have been a major force shaping various landscapes like Kaduna. His research revealed that built up area expanded at 167.86 annually and vegetation cover declined at the rate of 297.5 hectres annually. The unprecedented growth resulting to environmental and ecological problems associated with unplanned urban growth. In fact because of urbanization, it is said that Africa has experienced its best economic performance in many years. This has led to changing production and consumption patterns, economic expansion, new opportunities to move people through job creation as well as diversified livelihood options, Cleveland (2008).

More researches have shown same traits like that of the urban core of Nagoya city spread out to suburb over time. At the end of 90's decade, urbanization of this city began to slowdown. The characteristic of urbanization of Shanghai city was high urban density, and satellite towns around central city were established to absorb potential development to those satellite cities

This trend led to a negative impact of disorder, the configuration of Hanoi city areas in unusual shape, contributing to disorder in the urban shape getting along the transportation system.

Table 4 Abuja Population Trends and Projections $1981-2016$

\begin{tabular}{|l|l|l|}
\hline S/NO & Year & Population \\
\hline 1 & 1981 & 171,000 \\
\hline 2 & 1991 & 378,671 \\
\hline 3 & 1996 & 445,699 \\
\hline 4 & 2006 & $1,405,201$ \\
\hline 5 & 2016 & 2million \\
\hline
\end{tabular}

Source: Computed from the National Population Commission (NPC) Census and Estimates 2008

The population of Abuja and some of its environs in the last census conducted in 2006 within the study period were 1,405,201. Using exponential method for population projection, it was calculated that by the year 2016, a decade later, the population of the study area would have grown to $1,925,464.089$ which is about $37 \%$. 


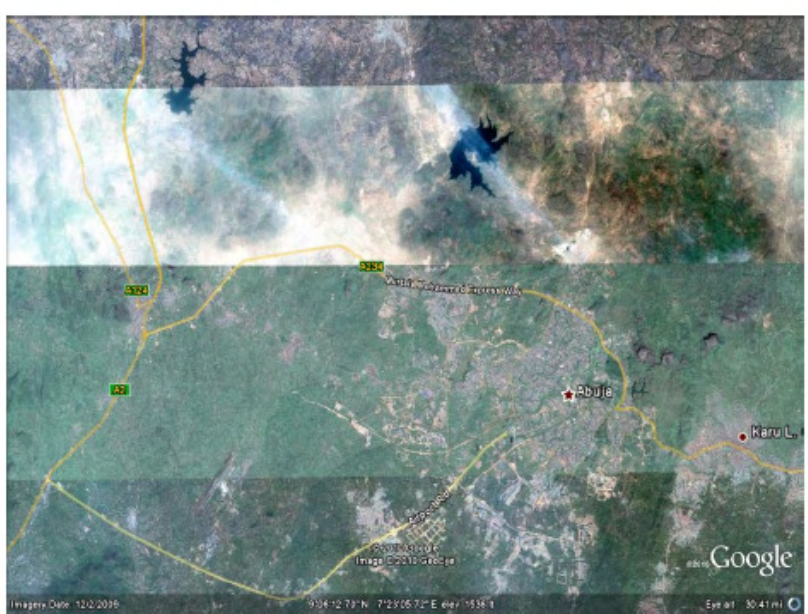

Plate 1 Picture Showing Abuja and Its Environs Source: Google earth (2010)

\section{Conclusion and Recommendations}

The result of this study from 1987 to 2007 has shown clearly the proximity of urban landuse which has negative impacts on the surrounding areas of the city. Furthermore, in the next (9) nine years if the growth rate is not put into check there will be shortage of resource in the city.

The built up area has increased from $49.9 \mathrm{~km}$ in 1987 to $93.77 \mathrm{kms}$ in 1999 and further increased to $179.48 \mathrm{kms}$ in 2007.This growth extends not just inwards but outwards implying that satellite towns surrounding the city are being affected posing a threat to limited available resources in the city and little or none in the satellite towns, the result of this is high cost of living.

According to the master plan of Abuja, development was to be in phases after a few years of take off, but almost four decades after we are still on the first phase which was planned for a few but now being utilized by a huge figure well out of the initial plan.

It is also observed that despite the fact that the other phases have not being officially opened up by government, there is a massive and illegal development with some encroaching on the master plan. It is therefore safe to say that Abuja is fast becoming like the nightmare of the last FCT which government was trying to burry with the dream of Abuja being the most beautiful capital/ city in Africa.

This research and review of similar works found out that despite efforts made at different quarters to check the sprawling growth of the

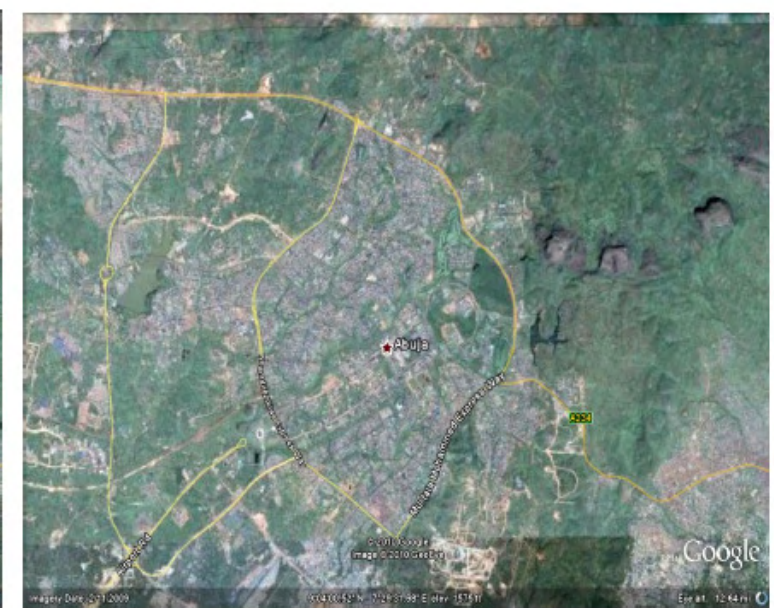

Plate 2 Picture Showing Abuja and Its Environs

Federal Capital Territory, Abuja master plan whose implementation is expected to make Abuja the pride of Nigeria, had suffered significant bastardizations pre-1999. Most physical development that contravened the provisions in the master plan are from the private sector, government, diplomats.Olujimi (2009). The cases of contravention in Abuja as analyzed are not unique to Abuja, there are features of the planning experience in other towns and cities in Nigeria, where growth is rapid and development control cannot cope with pressures of the development. Examples of these cities are Lagos, Enugu, Kaduna, Kano, Benin, Ibadan and Akure amongst others. However, the implementation of the Abuja master plan under the administration of the former president Olusegun Obasanjo (1999 -May 2007) controlled physical development in the city in spite of the political obstacles introduced by the previous administrations at bastardizing the master plan ( Olujimi 2009,Kalgo and Ayileka2001; Olujimi and Ayeni 2006).

Despite the issues of contravention, expansion and impacts as highlighted above, the United Nations Centre for Human Settlements UNCHS, observed that sustainable development is an integral component of human settlement development. This gives full consideration to the needs and requirement of achieving economic growth and development, social development, social progress, employment opportunities that are in harmony with the environment. Oluseyi (2006) 
Though land use changes are indirect consequence of national economic growth, it is important to evaluate land use changes in the regional and the local context in order to assist in anticipating the impacts associated with change and contribute to an understanding of productive environmental sustainability. It is not only necessary to understand the changed process in cities, the understanding of the agent of change of beneficiary of change can be useful indicators in planning and declaration of objective functions in cities.

However, for effective and functional urban growth management, data is required on changes taking place within and around the cities. Such data is vital to urban development and prevention of uncontrolled expansion and its consequences. For instance, land use changes require continuous updating of lands and their analysis so as to determine the rates and direction of city growth. These analysis and spatial information cannot be extracted from the out-dated hand drawn maps because most of the information contained therein are not necessary (Okosun; 2010; Adeboyejo and Abolade, 2006). It is worthy of note at this point that there are also varied policies for managing urban growth and most of the policies are centered around urban renewal, protecting open space in and around the city, Seoul's greenbelt, Brownfield's redevelopment etc.

Therefore, armed with the knowledge and findings from projects and research such as this, the development control, Federal Capital Development Authority (FCDA) and the necessary planning authorities should aggressively swing into action to forestall what is fast becoming like the Lagos nightmare.These planning authorities put in place are expected to control physical development in all parts of the city (including the sprawling areas). I must state here that they are on ground already but lack of political will to implement development control measures. Credit most also be given to the El-Rufai led administration that brought back the sanity we experience now.

Another effort at checking urban sprawl in FCT is the use of the provisions of the Nigerian Land Use Act of 1978. One of the objectives for the promulgation of the Nigerian Land Use Act in 1978 was to check urban sprawl and land speculation (Federal Government of Nigeria (FGN), 1978).
The law amongst others gives power to the government at the three different levels (Federal, State and Local government) to compulsorily acquire land within their areas of jurisdiction for development in the overall interest of the people. The Act however, provides for the payment of compensation for the existing development on the acquired land and not for undeveloped land. The implementation of the Act continues to witness hindrance because of the failure on the part of the government for not recognizing the cultural rights of the land-owners.

In summary, due adherence to development control /landuse act,urban renewal, greening, improved coordination between landuse planning and decision on municipal boundary changes, Local development and public regulation of urban sprawl are some of the recommendations of this work. Government policies are the sole or dominant cause of urban sprawl; we do presume that before adopting new policies designed to arrest or mitigate sprawl, it is wise to consider the effects on urban sprawl of policies currently in place.

\section{References}

Agboola, T. (2009), Sustainable Urbanization and the New Urban Planning Dilemma of New Opportunities and the Challenges for Nigeria Technocratic Planners a paper presented at the $2^{\text {nd }}$ Postgraduate Diploma Regular Forum Lecture Series in the Department of Urban and Regional Planning, Rufus Giwa Polytechnic, Quo, $3^{\text {rd }}$ June, 2000.

Anderson J.R. (1976) A landuse and landcover classification scheme for use with Remote sensing data.

U.S Geological survey professional paper.no 964 $36 \mathrm{pp}$

Ago, S. (2001), Implementation Of Master Plan: The Abuja Experience, 1979-1999. Proceedings Of An International Workshop For The Review Of The Abuja Master Plan, Held At The Ladi Kwali Conference Centre, Sheraton Hotel, Abuja From 29 November To $2^{\text {nd }}$ December 1999

Akrofi, E. O. (2006) Urbanization and the Urban Poor in Africa Kumasi: Kwame Nkrumah University of Science and Technology Press.

Cleveland, C. J. (2008). Environmental Change and Socioeconomic Factors Africa in 


\section{Monitoring Urban Sprawl in the Federal Capital Territory of Nigeria............Ade and Afolabi}

Encyclopedia of Earth United Nations Environmental Programme

David N.B (2004) Policies for managing urban growth and landscape change: A key to conservation in the $21^{\text {st }}$ century. Columbia University New York July 30-August 2

Debliy, H.J. (1996) Human Geography: Culture, Society and Space. New York: John Wiley and Sons.

Donny J.P, Barnsley M.J, and Longley P.A (eds), (1999). Remote sensing and urban analysis. London UK:Taylor and Francis

Ekoh O, Innocent O and Ogbonnaya O.(2006) ElRufai and Abuja Urban Renewal Policies:An Independent Study Crystal Print UK Ltd.

Hai, P.M. and Yamaguchi, Y. (2004) "Use of Remote Sensing to Monitor Urbanization of Hanoi City Center Japan: Nagoya University Pass.

Hardoy, J and D. Satterthwaite (1995) Squatter and Citizen: Life in the Urban Third World Earthscan Publications, London

Kombe, W. J. (1998). The Land Tenure and Land Use Planning: Question in the Urban Peripheries in Tanzania. Presented at the Seminar on Land Tenure and Policy Issues in Land Use Planning, August 17-28, 1998 Zschortau, Germany.

Okosun A.E, Ndukwu R.I and Chiemelu N.E (2010) Urban growth management of Nigerian cities: A GIS approach, Journal of Environmental Management and Safety vol 1 no 1: 165-179

Olarenwaju O. (2008) Remote sensing and GIS Applications in urban expansion and loss of vegetation cover in Kaduna town, Northern Nigeria. American Eurasian Journal of sustainable Agriculture

2.2 (2008):117-124

Olujimi, J. (2009). Evolving a Planning Strategy for Managing Urban Sprawl in Nigeria Journal of Human Ecology Vol. 25, No. 3:201-208

Oluseyi, O.F. (2006). Urban Land Use Change Analysis of a Traditional City from Remote Sensing Data: The Case of Ibadan Metropolitan Area Nigeria. Humanity and Social Science Journal Vol 1 No 1:42-64

Rao, L. K. (1995). Remote Sensing for Land Use Planning, International Jos of Remote Sensing 16:52-60

Rasaki, R. (1988). The Problems of Managing a Conurbation like Metropolitan Lagos in Africa Leadership Forum held in Ota, Nigeria from 24 October to 1 November, 1988.

Shuaib, L.S. (2000). Managing City Growth and Development in Context of Environmental Changes within Sub-Sahara Africa A Draft Paper Presented at International Potatoes Centre-Urban Harvest in Kampala. 